\title{
FINANSOWE ORAZ POZAFINANSOWE FORMY WSPARCIA STARTUPÓW W POLSCE
}

\author{
Justyna Kogut \\ Wydział Nauk Ekonomicznych i Prawnych \\ Uniwersytet Technologiczno-Humanistyczny im. Kazimierza Pułaskiego \\ w Radomiu
}

\begin{abstract}
Abstrakt. Startupy to nowo powstałe przedsiębiorstwa, które szukają szansy na dalszy rozwój. W Polsce kształtują się wciąż nowe i traktuje się je jako „zalążek” polskiej przedsiębiorczości, pracowitości czy też niezależności. Kluczem do innowacyjnej gospodarki są właśnie startupy. Nowe przedsiębiorstwo może powstać pod warunkiem posiadania odpowiedniej wielkości środków finansowych. Startupy mają wiele możliwości pozyskiwania kapitału i korzystania z wielu źródeł finansowania. Wybór właściwego zależy od wielu czynników, ale ostatecznie jest to indywidualna decyzja właścicieli przedsiębiorstwa.
\end{abstract}

Słowa kluczowe: startup, przedsiębiorstwa, finansowanie startupów, źródła finansowania przedsiębiorstw

\section{WSTĘP}

Działalność przedsiębiorstw ma znaczny wpływ na gospodarkę. Jest ona coraz częściej uzależniona od rozwoju tychże organizacji oraz od efektywnego prowadzenia działalności. Aby nowe przedsiębiorstwa mogły powstać, a te, które już działają, mogły zrobić „krok na przód”, potrzebne jest konkretne źródło finansowania. W aktualnym świecie gospodarczym każde przedsiębiorstwo, aby móc funkcjonować oraz wypracować mocną i trwałą pozycję rynkową, musi mieć pewną podstawę gwarantującą rozwój. Z całą pewnością do tego „fundamentu” należy zaliczyć środki finansowe. Uwzględniając ich duże znaczenie w osiąganiu sukcesu biznesowego, niezwykle zasadne wydaje się ciągłe monitorowanie i badanie tego zagadnienia. 
Celem pracy jest zatem analiza finansowych oraz pozafinansowych form wsparcia przedsiębiorstw typu startup w Polsce w latach 2015-2016. W części teoretycznej scharakteryzowano startupy oraz finansowe i pozafinansowe form ich wsparcia. W części empirycznej dokonano analizy statystycznej danych otrzymanych w wyniku badań wtórnych przeprowadzonych przez Fundację Startup Poland w latach 2015-2016 i zaprezentowanych w dwóch raportach „Polskie startupy”.

\section{CHARAKTERYSTYKA PRZEDSIĘBIORSTW TYPU STARTUP}

Termin startup wykorzystywany jest zaledwie od kilku lat i przez to m.in. nie ma formalnej definicji [Andrulonis 2015]. Należy jednak przytoczyć kilka wyjaśnień tego pojęcia. Eric Ries, twórca koncepcji startupów oraz autor poradnika „Metoda Lean Startup”, podaje w nim następujące tłumaczenie: „Startup to ludzka instytucja stworzona z myślą o budowaniu nowych produktów lub usług w warunkach skrajnej niepewności". Można to rozumieć jako tworzenie przedsiębiorstwa zarządzanego przez zespół ludzi, takiego, które byłoby innowacyjne, choć bez gwarancji powodzenia [Ries 2011]. Definicja zaproponowana przez Riesa została odtworzona na dwuwymiarowym układzie współrzędnych przedstawionym na rysunku 1.

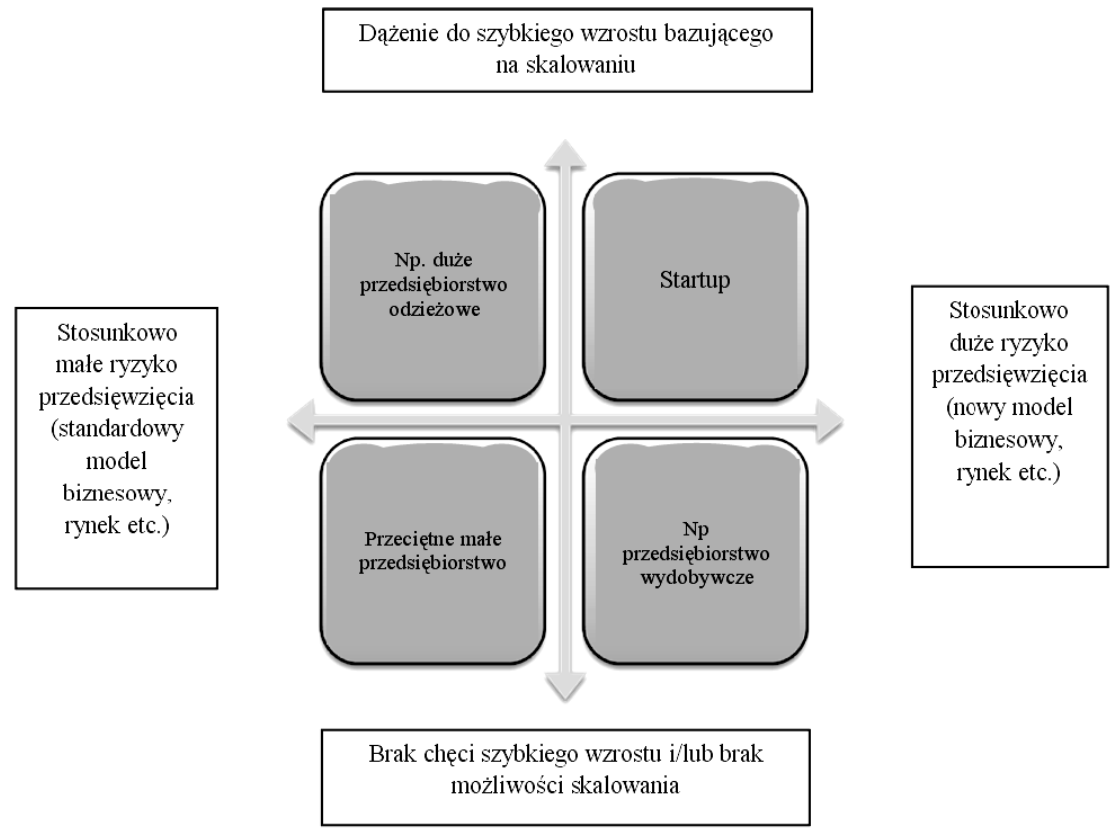

RYSUNEK 1. Umiejscowienie startupu na mapie ryzyka i skali przedsięwzięć biznesowych Źródło: Deloitte Polska 2016. 
Startupy traktuje się jako pewnego rodzaju eksperymenty. Tworząc je, należy nastawić się na ciągłe poszukiwanie w warunkach nieustających zmian ekonomicznych. Celem startupów jest znalezienie takiego modelu biznesowego, który sprzyjałby osiągnięciu stabilnego i systematycznego dochodu.

Normalne przedsiębiorstwa mają wypracowany stały sposób na zarabianie pieniędzy. Startupy zaś muszą cały czas go poszukiwać. Podobna sytuacja kształtuje się w modelu biznesowym, ponieważ zwykłe przedsiębiorstwa cały czas realizują obrany model. Startupy natomiast napotykają na wiele niepowodzeń w trakcie kształtowania takiego modelu [Szymański 2014].

Blank definiuje startupy jako: „organizacje stworzone w celu poszukiwania powtarzalnego i skalowalnego modelu biznesowego". Blank zwrócił szczególną uwagę na określenie celu tworzenia startupu. Jego zdaniem ma być nim osiągnięcie regulowanego modelu biznesowego, który będzie pozwalał na zdobywanie kolejnych rynków i rozwój przedsiębiorstwa [Blank 2010].

\section{CHARAKTERYSTYKA FINANSOWYCH ORAZ POZAFINANSOWYCH FORM WSPARCIA STARTUPÓW}

Przedsiębiorstwa w różnych cyklach swojej działalności, zarówno nowo powstałe, jak i już długo funkcjonujące, muszą pozyskiwać kapitały na swoją dalszą działalność oraz rozwój. Sposób pozyskiwania środków finansowych oraz korzystanie z niefinansowych form wsparcia zależy głównie od aktualnego etapu rozwoju organizacji, jej wielkości oraz perspektywy jej rozwoju [Waga 2014].

Przedsiębiorstwo, prowadząc swoją działalność, wykorzystuje kapitał pochodzący z różnych źródeł finansowania. Z punktu widzenia źródła pochodzenia kapitału wyróżnia się finansowanie wewnętrzne i zewnętrzne. Finansowanie wewnętrzne określane jest mianem samofinansowania i występuje $w$ funkcjonującym już podmiocie. Finansowanie zewnętrzne zaś charakteryzuje dopływ środków spoza przedsiębiorstwa.

W momencie powstawania organizacji przedsiębiorcy zazwyczaj finansują swoją działalność gospodarczą ze środków własnych. Niekiedy są one niewystarczającym źródłem finansowania i dlatego inwestorzy korzystają z kapitałów obcych, takich jak: aniołowie biznesu, venture capital, leasing, faktoring, franchising.

Aniołowie biznesu to podmioty które działają w części rynku nieformalnego nieregulowanego, nieinstytucjonalnego, tzw. private equity. Mogą to być osoby indywidualne lub grupy inwestujące swoje środki finansowe w zakup akcji lub udziałów przedsiębiorstw posiadających duży potencjał rozwojowy, ale równoczesnie obarczonych dużym ryzykiem [Piekunko-Mantniuk 2014]. 
Venture capital to forma finansowania przedsiębiorstw polegająca na wnoszeniu kapitału na ograniczony czas przez inwestorów zewnętrznych do małych i średnich przedsiębiorstw, które dysponują produktem, metodą produkcji bądź usługą stwarzającą duże ryzyko niepowodzenia, lecz w przypadku sukcesu przedsięwzięcia zapewniającego duży przyrost wartości zainwestowanego kapitału [Rosa 2008]. Venture capital jest częścią private equity, czyli inwestycji dokonywanych we wczesnych fazach rozwoju przedsiębiorstwa i służących jego uruchomieniu lub ekspansji. Należy pamiętać, iż obydwa pojęcia często stosowane są zamiennie, przy czym venture capital dotyczy inwestowania mniejszych kwot niż private equity [Fałat-Kilijańska 2011].

Leasing jest kolejnym źródłem finansowania przedsiębiorstw. Polega on na przekazaniu przez leasingodawcę środka trwałego lub wartości niematerialnej i prawnej, określonej w umowie, w zamian za z góry ustalone czynsze (raty) leasingowe [Brezeanu 2011]. Raty płatne są najczęściej w odstępach miesięcznych, choć mogą być płatne w odstępach krótszych lub dłuższych niż 30 dni. Wszystko zależy od zapisów w umowie leasingowej. Okres leasingu jest w dużej części regulowany przez prawo, ale tylko jeśli chodzi o jego minimalny zakres [Owsiak i Pruchnicka-Grabias 2006].

Faktoring polega na nabywaniu przez specjalistyczne instytucje faktoringowe bieżących, nieprzeterminowanych i niespornych wierzytelności od podmiotów gospodarczych, którym należności te przysługują z tytułu dostarczanych towarów i usług. Jest to forma kredytowania należności i jednocześnie jest operacją rozliczeniową polegającą na inkasowaniu należności [Wolak-Tuzimek i in. 2015].

Franchising często określany jest jako forma alternatywna finansowania kapitału wobec leasingu, stanowi bowiem sposób pozyskania dostępu do rynku, nowych technologii przez przedsiębiorstwo, które nie posiada wystarczających środków finansowych, aby utworzyć firmę o silnej pozycji na rynku [Premner i Hatch 2001]. Podstawą franchisingu jest umowa, według której w zamian za odpowiednią opłatą można uzyskać prawo do utworzenia i prowadzenia przedsiębiorstwa zgodnie z pomysłem, sposobem zarządzania, wykorzystując doświadczenie i sprzęt franchisingodawcy oraz działając pod jego znakiem firmowym.

Franchising to metoda poszerzania rynków zbytu danego rodzaju aktywności gospodarczej poprzez kształtowanie sieci jednolitych placówek, które prowadzą swoją działalność na terenach oddalonych od siedziby głównego organizatora. Wszystkie punkty danej sieci powierzane są osobom trzecim [Wolak-Tuzimek 2010].

Kolejną formą finansowania jest kredyt bankowy oraz pożyczka. Choć uważa się, że są to tożsame narzędzia, to jednak w pewnym stopniu się różnią. Podstawą udzielenia kredytu jest umowa zawierana między bankiem a kredytobiorcą (osoba prywatna, firma, instytucja). W wyniku ustaleń bank udostępnia określoną 
sumę pieniędzy kredytobiorcy, zaś kredytobiorca przeznacza te środki na dany cel i zobowiązuje się do ich zwrotu w określonym terminie wraz z prowizją i naliczonymi odsetkami. Pożyczka to zaś czynność polegająca na oferowaniu określonej sumy pieniędzy pożyczkobiorcy przez osoby fizyczne lub instytucje [Wolak-Tuzimek i in. 2015].

Oprócz opisanych form wsparcia, startupy korzystają także z wielu innych. Należą do nich: akceleratory, inkubatory przedsiębiorczości, crowdfunding czy dotacje (środki finansowe) z Unii Europejskiej (UE).

Inkubatory to instytucje, które wspierają przedsiębiorczość, dając zwykle znaczny wkład finansowy w zamian za większe udziały w startupie. Inkubatory oferują nowo powstałym firmom pomoc o charakterze innowacyjnym. Zazwyczaj wsparcie to świadczone jest $w$ początkowej fazie istnienia danych organizacji i jest uzależnione od statutu organizacji. Może trwać od roku do nawet kilku lat. Inkubatory oferują m.in.: doradztwo ekonomiczne, prawne czy finansowe, kontakty z instytucjami naukowymi i ocena przedsięwzięć innowacyjnych, pomoc w pozyskiwaniu środków finansowych oraz tworzenie właściwego klimatu dla podejmowania działalności gospodarczej i realizacji przedsięwzięć innowacyjnych [Matusiak 2006].

Akceleratory to programy wspierające biznes w podobny sposób do inkubatorów przedsiębiorczości. W zamian za niewielkie udziały w firmie akceleratory oferują miejsce do pracy, wsparcie mentorów i pomoc w pozyskiwaniu kapitałów. Dzięki akceleratorom startupy otrzymują porady dotyczące aspektów związanych z zarządzaniem podmiotem gospodarczym. Różnią się od inkubatorów jedynie mniejszą liczbą procedur urzędniczych, przez które muszą przejść, oraz atmosferą podczas spotkań z mentorami, którą można porównać do przyjacielskiej.

Jedną z form pozyskiwania środków jest także crowdfunding, czyli finansowanie społecznościowe [Grabiec 2015]. W szerszym ujęciu crowdfunding polega na niemal dowolnej formie gromadzenia środków finansowych poprzez sieć komputerową. W węższym ujęciu zaś stanowi proces, w którym np. przedsiębiorcy, artyści czy organizacje pozarządowe zbierają środki finansowe na potrzeby różnych przedsięwzięć, projektów lub organizacji, bazując na wsparciu wielu osób, które wspólnie przeznaczają pieniądze na dane inwestycje bądź sami w nie inwestują [Dziuba 2012]. Zdarza się również, że w zamian za obietnice podarowania różnorodnych gadżetów, prezentów czy też pierwszej wersji opracowanego produktu startupy otrzymują od inwestorów środki finansowe [Grabiec 2015].

Finansowych oraz niefinansowych form wsparcia przedsiębiorstw jest wiele. Ciężko jest stwierdzić, która $\mathrm{z}$ nich jest najkorzystniejsza. To już stanowi indywidualną sprawę każdej organizacji i jest uzależnione również od wewnętrznej analizy czynników rozwoju firmy oraz od otoczenia zewnętrznego. 


\section{FORMY FINANSOWEGO ORAZ POZAFINANSOWEGO WSPARCIA STARTUPÓW W POLSCE - WYNIKI BADAŃ}

„Polskie startupy 2016” to raport z badań przeprowadzonych przez Fundację Startup Poland w 2016 roku (od 4 lipca do 15 sierpnia) wśród 692 podmiotów w Polsce. Metodą badań był kwestionariusz ankietowy, który wysłano dwukrotnie w wiadomości e-mail do 2677 startupów znajdujących się w bazie. Z częścią nawiązano zaś kontakt telefoniczny. „Polskie startupy 2015” to raport z badań przeprowadzonych przez Fundację Startup Poland w 2015 roku (od 10 czerwca do 15 września) wśród 423 podmiotów w Polsce. Metodą badań był kwestionariusz ankietowy, który został wysłany dwukrotnie w wiadomości e-mail do 2432 startupów znajdujących się w bazie. Z częścią nawiązano także kontakt telefoniczny.

Wyniki analizy startupów wskazują na to, że zarówno w 2015 roku, jak i w 2016 roku źródłem kapitału w startupach były środki własne (odpowiednio 59 i 79\%). Dotacje z UE były drugą formą finansowania działalności w obydwu badanych okresach. W przypadku korzystania z venture capital można zaobserwować wzrost liczby podmiotów korzystających z tej właśnie formy finansowania (z 18\% w 2015 roku do 22\% w 2016 roku). Odwrotna sytuacja wystąpiła w przypadku aniołów biznesu. Porównując dwa badane okresy, liczba podmiotów korzystających z tego źródła finansowania zmniejszyła się (z 20 do 17\%). Jak wynika z przeprowadzonych badań, źródłem kapitału w startupach są także kredyty i pożyczki zaciągnięte w bankach. W 2015 roku z tej formy działalności skorzystało niewiele, bo 8\% badanych podmiotów. W 2016 roku liczba ta zmniejszyła się do 6\% respondentów. Interesujący aspekt stanowią nowe źródła kapitału w startupach, które pojawiły się w ankiecie w 2016 roku, a których do wyboru nie mieli ankietowani uczestniczący w badanie rok wcześniej. Należy do nich akcelerator, z którego skorzystało 7\% podmiotów, oraz strategiczny inwestor branżowy, z którego skorzystało 6\% podmiotów (rysunek 2).

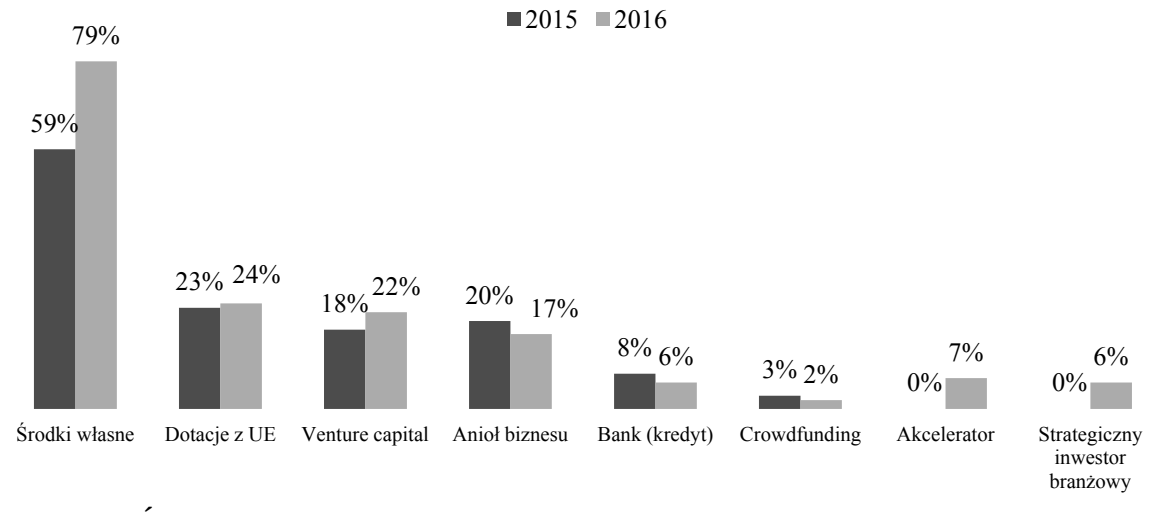

RYSUNEK 2. Źródła kapitału w startupach w latach 2015-2016 (wielokrotny wybór) Źródło: Opracowanie własne na podstawie: Startup Poland [2016]. 
Pytanie dotyczące zewnętrznych źródeł finansowania, które respondenci zamierzają pozyskać $\mathrm{w}$ ciągu najbliższych sześciu miesięcy pojawiło się dopiero w ankiecie skonstruowanej w 2016 roku. Wyniki zaprezentowane w raporcie wskazują na to, iż na pierwszym miejscu uplasowały się fundusze venture capital. Aż 59\% ankietowanych wskazało właśnie tę formę finansowania. Niewiele mniej otrzymały dotacje z UE (56\%). Na trzecim miejscu znaleźli się aniołowie biznesu (35\%). Z kolei 10\% przedsiębiorców zapowiedziało, że będą korzystali z takiej formy wsparcia jak kredyt bankowy. Jeżeli chodzi o crowdfunding, to mimo że ma znikomy udział w finansowaniu przebadanych startupów to $11 \%$ respondentów zadeklarowało, że będzie starać się pozyskać środki z tego źródła (rysunek 3).

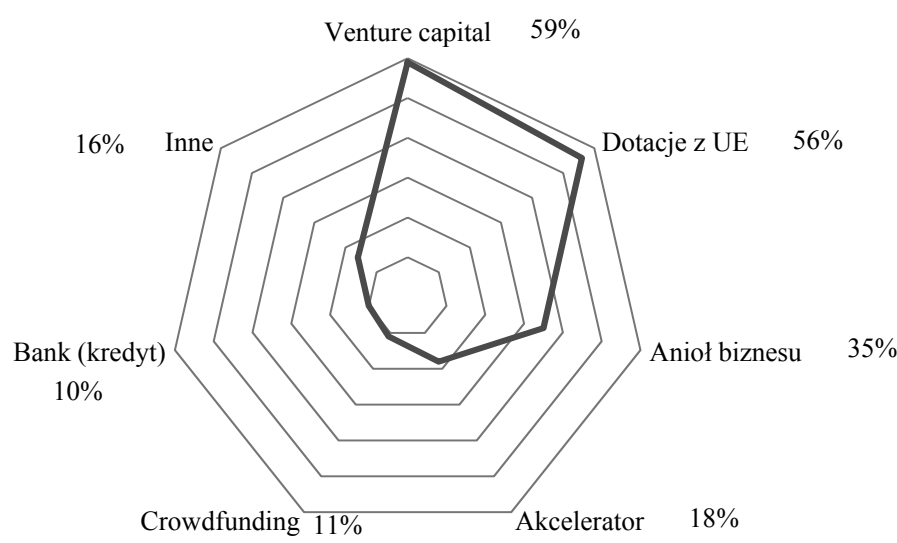

RYSUNEK 3. Planowanie pozyskania zewnętrznych źródeł finansowania przez startupy w ciągu najbliższych sześciu miesięcy na podstawie badań ankietowych

Źródło: Opracowanie własne na podstawie Startup Poland [2016].

Należy również przeanalizować niefinansowe środki wsparcia, z którego korzystały startupy w latach 2015 i 2016. Można zauważyć, że w 2016 roku wzrosła liczba startupów, które skorzystały z takich form, jak spotkania branżowe (w 2015 roku było to $12 \%$ podmiotów, a w 2016 roku już 41\%), udział w Startup Weekendzie $^{1}$ (wzrost z 7\% w 2015 roku do 32\% w 2016 roku) czy udział w konkursie startupowym (w 2015 roku zadeklarowało 12\% podmiotów, a w 2016 roku już 37\%). Wzrosło również zainteresowanie mentoringiem, akceleratorem czy inkubatorem. Należy nadmienić, iż w 2016 roku, 31\% ankietowanych podmiotów wskazało również inne formy wsparcia, z których korzystali. W 2015 roku respondenci nie mieli takiej opcji do wyboru (rysunek 4).

\footnotetext{
${ }^{1}$ Startup Weekend to cykliczna, międzynarodowa impreza przeznaczona dla otwartych, kreatywnych oraz przedsiębiorczych ludzi. Jest to trzydniowy zjazd, trwający bez przerwy, w czasie którego w ciągu 54 godzin skompletowany na miejscu zespół, przygotuje fundamenty startupu, prototyp usługi, narzędzia czy serwisu (www.startupweekend.org).
} 


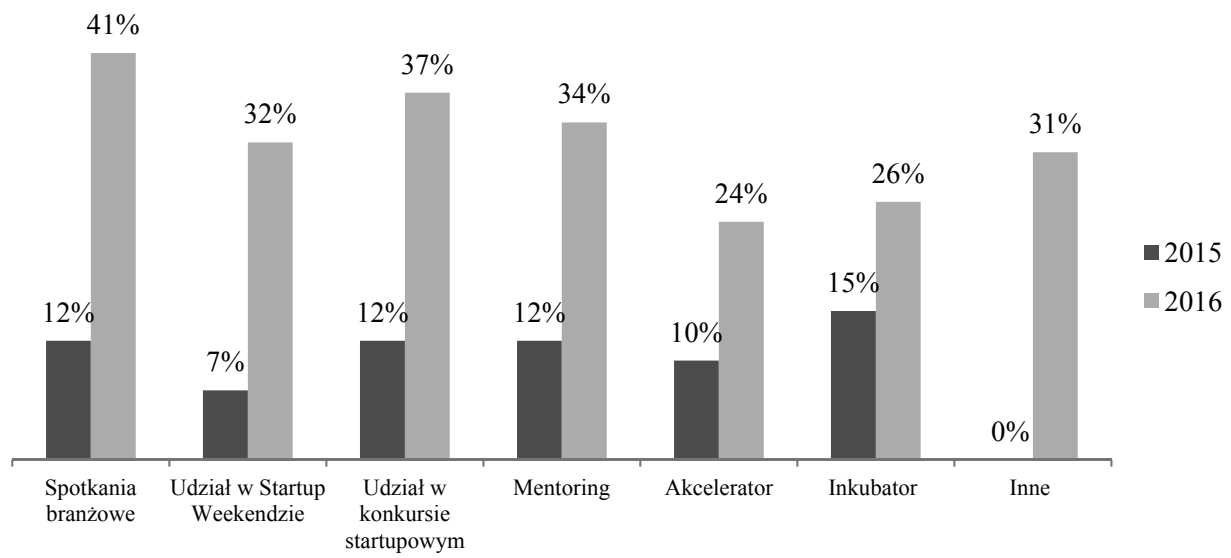

RYSUNEK 4. Niefinansowe środki wsparcia startupów w latach 2015-2016 (wielokrotny wybór)

Źródło: Opracowanie własne na podstawie Startup Poland [2016].

Podsumowując wyniki badań w raporcie „Polskie startupy 2015” oraz raporcie „Polskie startupy 2016” można stwierdzić, iż na przełomie tych dwóch lat, źródła finansowania wskazane przez badane podmioty diametralnie się zmieniły. Choć przedsiębiorstwa nadal w dużej mierze korzystają tylko ze środków własnych, to jednak coraz chętniej sięgają po takie formy finansowania swojej działalności, jak: dotacje unijne, venture capital, aniołowie biznesu czy kredyty bankowe. Co ciekawe, startupy korzystają też z innych form wsparcia. Spotkania branżowe, udział w konkursach i imprezach, mentoring czy akcelerator to tylko niektóre z wielu niefinansowych środków wsparcia startupów.

\section{WNIOSKI}

Finansowanie stanowi jeden z podstawowych czynników funkcjonowania każdego przedsiębiorstwa. Wpływa na powstawanie firmy i jej dalszy rozwój, skłonność do inwestowania czy też zatrudnienia oraz na wiele innych aspektów.

Startupy to zaś organizacje, które istnieją i działają dzięki środkom finansowym. Istnieje wiele form, instytucji czy też osób prywatnych, które proponują pomoc pieniężną nowo powstałym przedsiębiorstwom. Organizacje wybierają zazwyczaj tą, która jest najbardziej korzystna dla nich, uwzględniając jednocześnie wiele czynników, do których należy: wielkość przedsięwzięcia, otoczenie zewnętrzne czy też łatwość $w$ pozyskiwaniu funduszy.

Wyniki analizy finansowania startupów wskazują na to, iż w latach 2015-2016 najpopularniejszym źródłem kapitału w startupach były środki własne 
(w 2015 roku wskazało tę formę 59\% ankietowanych, a w 2016 roku aż 79\% ankietowanych). Coraz częściej zaś przedsiębiorcy decydują się na korzystanie ze wsparcia zewnętrznych źródeł. Popularne są w tym przypadku dotacje z UE, venture capital czy też aniołowie biznesu. Przedsiębiorcy zadeklarowali również, że chcą nadal z nich korzystać w perspektywie najbliższych sześciu miesięcy. $\mathrm{Na}$ pozyskanie środków z venture capital zdecydowałoby się $59 \%$ respondentów, na dotacje unijne $-56 \%$, a z pomocy aniołów biznesu skorzystałoby - $35 \%$ ankietowanych. Inne formy finansowania są nadal mniej rozpowszechnione. Jednak oprócz nich na popularności zyskały niefinansowe środki wsparcia startupów. Średnio o około 30\% wzrosło zainteresowanie spotkaniami branżowymi, imprezami czy konkursami startupowym, mentoringiem oraz akceleratorami. Świadczy to o zwiększeniu świadomości polskich przedsiębiorców startup możliwości finansowania swojej działalności z różnorodnych i co ważne nowych źródeł, a także pośrednio dowodzili, że chcą oni dalej rozwijać się na rynku gospodarczym.

Podsumowując, finansowanie startupów w Polsce stanowi fundament ich powstania oraz dalszego funkcjonowania. Jest wiele źródeł finansowania przedsiębiorstw. Z pewnością ta, która zostanie uznana za najbardziej odpowiednią, choć obarczona ryzykiem przedsięwzięcia, daje możliwość udoskonalenia pomysłów i przetrwania na rynku gospodarczym.

\section{Spis literatury}

ANDRULONIS K. 2015: Część I: Co to jest startup i jak się za to zabrać, http://europa.eu/ youth/pl/article/58/30350_pl [dostęp: 01.02.2017].

BLANK S. 2010: What's A Startup? First Principles. https://steveblank.com/2010/01/25/ whats-a-startup-first-principles [dostęp: 02.02.2017].

BREZEANU P. 2011: Finanțele personale în România, C.H. Beck Publishing House, Bucharest.

Deloitte Polska 2016: Diagnoza ekosystemu startupów w Polsce. Raport.

DZIUBA D.T. 2012: Rozwój systemów crowdfunding - modele, oczekiwania i uwarunkowania, Problemy Zarządzania 10, 3 (38), 83-103.

FAŁAT-KILJAŃSKA I. 2011: Prawne aspekty tworzenia i funkcjonowania funduszy private equity. Przegląd przyjętych rozwiązań w wybranych krajach europejskich, Zeszyty Naukowe Polskiego Towarzystwa Ekonomicznego 11, 297-310.

GRABIEC P. 2015: Czym jest startup? Wchodzimy w świat nowoczesnego i dynamicznego biznesu, http://www.pcworld.pl/news/Czym.jest.startup.Wchodzimy.w.swiat. nowoczesnego.i.dynamicznego.biznesu,404031.html [dostęp: 03.02.2017].

MATUSIAK K. 2006: Rozwój systemów wsparcia przedsiębiorczości. Przesłanki, polityka i instytucje. Instytut Eksploatacji, Radom-Łódź. 
OWSIAK K., PRUCHNICKA-GRABIAS I. 2006: Leasing [w:] I. Pruchnicka-Grabias, A. Szelągowska (red.), Finansowanie działalności gospodarczej w Polsce. Wybrane aspekty, CeDeWu, Warszawa.

PIEKUNKO-MANTNIUK I. 2014: Aniołowie Biznesu i ich rola w finansowaniu startupów, Economics and Management 4, 366.

PREMNER H., HATCH J.E. 2001: Franchising, Ivey School of Business, The University of Western Ontario, London-Ontario.

RIES E. 2011: The Lean Startup, Crown Business, London.

ROSA A. 2008: Venture Capital w Polsce, Zeszyty Naukowe Wydziału Nauk Ekonomicznych Politechniki Koszalińskiej 12, 133-143.

Startup Poland. 2015: Polskie startupy 2015. Raport.

Startup Poland. 2016: Polskie startupy 2016. Raport.

SZYMAŃSKI M. 2014: Startup - czym jest i dlaczego powinieneś się nim zainteresować, https://biznesflow.pl/czym-jest-startup [dostęp: 01.02.2017].

WAGA M. 2014: Źródła finansowania małych i średnich przedsiębiorstw, Infos 7.

WOLAK-TUZIMEK A. 2010: Determinanty rozwoju małych i średnich przedsiębiorstw w Polsce, Wydawnictwo Naukowe PWN, Warszawa.

WOLAK-TUZIMEK A., DUDA J., SOŁOMA A., LAMENT M. 2015: Zarządzanie małym i średnim przedsiębiorstwem. Wybrane problemy, Wydawnictwo Naukowe Spatium, Radom.

\title{
STARTUPS FUNDING IN POLAND
}

\begin{abstract}
Startups are newly created companies that are looking for further development opportunity. There are still new ones arising in Poland and they are considered as a "seed" of Polish entrepreneurship, diligence and independence. The key to innovative economy are exactly startups. To create a new company, adequate financial resources are necessary. Startups can acquire capital in many ways. Choosing appropriate depends on many factors, but it the end, the enterprise's owners decide which one to choose.
\end{abstract}

Key words: startup, companies, startups financing, sources of enterprises financing 